\title{
Research on Development Strategies of Red Tourism of Guangxi under the International Background Xinyu Xiong ${ }^{1, \text { a }}$
}

\author{
${ }^{1}$ Guilin Tourism University, Guilin, 541000, China \\ ${ }^{\mathrm{a}}$ email
}

\section{Keywords: Red tourism, Guangxi tourism, International Background}

\begin{abstract}
The red tourism in Guangxi is attracting more and more overseas tourists, and has become an important brand of Guangxi tourism. Under the new conditions, it is of great significance to analyze the advantages, disadvantages, opportunities and challenges of the red tourism in Guangxi, and give the strategic recommendations of the red tourism in Guangxi. The strategies presented in this paper include increasing international publicity, innovating international products, cultivating internationalized talents and developing international lines.
\end{abstract}

\section{Introduction}

The red tourism in Guangxi has shown a good momentum of vigorous development and achieved remarkable political, economic and social benefits in recent years. The success of red tourism has created a resounding brand, and its popularity and reputation have been continuously improved. The red tourism of Guangxi has become one of the most popular tourism business for the masses. The number of visitors of red tourism in Guangxi has increased from 18 million in 2011 to 26 million in 2014 with an average annual growth rate of $12.6 \%$. Most of the tourists are domestic tourists, especially government officials. The red tourism of Guangxi has played an important role in social education. It has promoted the red culture and inherited the red gene. The red tourism of Guangxi has promoted the coordinated development of the economy and society of the old revolutionary areas. It is also a poverty alleviation project and people's morale project. At present, the development of red tourism of Guangxi has basically formed a system with wide range content and rich distinctive features. In addition to standardizing and strengthening the use of information means, we should also strengthen the internationalization development strategy of the red tourism of Guangxi in the future. In fact, the red tourism of Guangxi has been concerned by many countries and regions in the world for a long time. With the rapid development of tourism industry, the red tourism industry also has the basis and conditions for international development. In the future, Guangxi should actively explore cooperation patterns and mechanisms to enhance international exchange. It is a new bright spot for the development of the red tourism of Guangxi. We should strengthen the international perspective of the red tourism of Guangxi so that the red tourism resources of Guangxi can step to the world further to attract more overseas tourists.

\section{SWOT Analysis of Red Tourism of Guangxi}

Strength. Red tourism is not simply a tourism resource. On the contrary, it not only possesses touring elements such as local folk customs and natural landscapes but also reflects the authentic depiction of revolutionary history. In addition, it is the scenic spot of revolutionary significance, monument and the revolutionary spirits formed by the Chinese people who made significant contributions in the periods of revolutionary struggle and construction. For many overseas tourists, it is possessed of "defamiliarization" in the sense of aesthetics which has a unique appeal and market development potential. Red tourism is abundant in resources and varies intensively. The red tourism resources in Guangxi are mainly distributed in old revolutionary base areas centered as Baise and Northeast Guangxi centered as Guilin, and the relatively concentrated distribution of resources provide material base to some extent for the internationalization of red tourism in Guangxi. What's 
more, the location of the red tourism enjoys obvious advantages which are close to the international tourist market. It is also adjacent to ASEAN countries with a huge ASEAN market of 530 million people, thus laying a solid foundation for the internationalization of red tourism in Guangxi.

Weakness. Product connotation still remains to be excavated and it is insufficient in expressing national characteristics. In the development of red tourism in Guangxi, it is defective in propagandizing national unity and embodying national characteristics. It is increasingly serious in the discovery of national stories and the theme of red tourism. In addition, the product system remains to be improved, and the industry is still at the initial stage. From the perspective of the industrial chain, the industrialization level of red tourism in Guangxi is comparatively low which fails to form a streamlined industrial system integrating six elements as a whole of tourism services. The market operation system of red tourism has not yet been fully established, and ways of display are monotonous and attraction in scenic spots needs to be improved. What's more, the size of most red tourism in Guangxi is small, and the core resources in those areas are museums and memorial halls. As a result, the museum is insufficient in display ways, expression methods, modernity and experience-oriented projects. The items invested are simplified which call for the participation of a diverse market. At present, the marketing channels of red tourism in Guangxi is simplex that are featured with flourishing government but desolate enterprises, obstreperous media but indifferent public and numerous tourists but few benefits. Compared with the demand of the development of tourism and surrounding provinces and cities, there's a large gap of capital investment of publicity and promotion in Guangxi. Last but not the least, the level of development of economy and society in red tourism is comparatively low and the infrastructure construction there is lagging behind.

Opportunity. Under the background of "The Belt and Road", China implements the development strategy of red tourism of "New Silk Road, New Red Tourism and New Experience", which will inevitably contribute to the investment and construction of red tourism of countries along and attract more tourists to go for a travel along "The Belt and Road", thus enhancing the development vitality of red tourism vitality. In addition, it will vigorously push the rapid development of red tourism. In view of natural and human factors, Guangxi is extremely abundant in natural and historical human resources. However, these resources there fail to obtain an excellent development due to the restriction of transportation and so on. On the contrary, it helps Guanxgi retain many original ecological and superior resources. The proposal of "The Belt and Road" exactly endows the red tourism in Guangxi with fantastic opportunities. By virtue of the sound momentum of the development of red tourism, the corresponding ancillary facility and service ability there will be mightily perfected and enhanced. In conclusion, under the continuous influence of "The Belt and Road", red tourism will undoubtedly enjoy a more and more significant position in the industries in Guangxi.

Thereat. It can't be overlooked that it will inevitably incur a series of challenges when driving the development if red tourism in Guangxi under the strategy of "The Belt and Road". Apart from competing with other domestic provinces and cities, Guangxi tourism will embark on the international arena to face the challenges from Southeast Asia and other countries. Compared with these Southeast Asian countries, coastal resources in Guangxi are overshadowed. Then how to make full use of its uniqueness and innovation becomes particularly important. Even though the red tourism resources in Guangxi are rich, the development speed and degree of other domestic red tourism areas hold a safe lead than those in Guangxi. As a result, the internationalization of red tourism in Guangxi is faced with competition with other domestic scenic spots. The development models and products of red tourism in Guangxi are monotonous which is also unsuccessful in winning back international tourists. Currently, all parts of the country including Hunan, Guizhou, Sichuan, Jiangxi and other provinces and cities are also actively building their own red tourism brands. All these provinces and cities mentioned above are possessed of considerable strength and advantages. The tourist resources of folk customs are widely distributed in many areas of Guangxi. Therefore, issues such as duplicated red tourism resources and homogenized red tourism products among various districts and counties. 


\section{Development Strategies of Red Tourism of Guangxi under the International Background}

Increase International Publicity of Red Tourism. It is necessary to serve the cooperation and exchange as an important strategic grasp of the internationalization of red tourism, the main purpose of which is to expand and build a new bilateral and multilateral relationship through mutual cooperation and exchange of red tourism between China and Vietnam so as to create the atmosphere of the internationalization of red tourism. For both China and Vietnam, it is of great demonstration effect to jointly hold activities concerning cooperation and exchange of red tourism. The internationalization of red tourism in Guangxi has possessed conditions to some extent currently. As a local brand in Guangxi, red tourism has attracted more and more attention of the public opinion. The red tourism is no longer confined to the country. In contrast, it is becoming a new fashion for Chinese people to "take a red tourism in foreign countries". In May 2017, Longzhou County has successively held "The Closing Ceremony of Sino-French Cultural Exchange and Opening Ceremony of International Art Center in Longzhou", "First Valentines' Day between Longzhou, China and Vietnam", "Sino-Vietnamese Cross-border Mountain Run" and so on, which enhance and expand the visibility and influence of Longzhou at home and abroad. What's more, these activities also expand the new field of cooperation and development of transnational tourism, injecting new vitality into tourism, economy and cultural development. Under the drive of the major tourism projects, Longzhou County elaborately draws a new picture of its tourism. Apart from that, the development of red tourism in Giangxi is supposed to be actively integrated with "The Belt and Road" and "Internet plus" so as to lift the international level of the marketing of red tourism. At present, the marketing of red tourism in Guangxi still fights alone. Therefore, if hoping to speed up the internationalization of red tourism in Guangxi, the government should be engaged to take measures to integrate the existing marketing channels and marketing tools so as to internationally establish a unique red tourism brand in Guangxi.

Innovate International Products of Red Tourism. It is suggested to create internationally cooperated zones of red tourism so as to further integrate the cultural tourism, green tourism, border tourism and rural tourism resources in Longzhou and Gao, Vietnam, thus establishing the transitional red tourism brand. Taking the Red Tourism Bases in Baise and Donglan as the typical, the international red tourism base can hence be built. In addition, it is necessary to intensify the protection of red resources in Red Tourism Base in Baise and improve the construction of scenic spots there. Also, it is of vital significance to perfect the facility, enrich the sightseeing and improve the services of the system of red tourism. Apart from that, it is urgent to carry out the continued projects including AAAAA project in Baise Revolt Monument, Base of Revolutionary Tradition and Patriotism in Tiandong, Headquarters of 7th and 8th Corp, Chinese Workers' and Peasants' Red Army in Le'ye and so on. Meng Ma-North Vietnam Red Tourism Zone and Patriotism Education Base in An'ding Town, Tianlin County are newly added. In addition, it is vital to promote cross-border red tourism routes, improve the traffic operation system, create poverty reduction pattern of red tourism and revitalize Revolutionary Base Area in the Zuo Jiang and You Jiang Region. By virtue of the health preservation for longevity and the development of ecological tourism resources, it can dig out the characteristics and cultures of minorities in Red Tourism Base in Donglan, push the combination of "red" and "green" and promote the integral development of red tourism and a variety of tourisms. What's more, it is necessary to further speed up the traffic construction, improve the accessibility of the destination, fully excavate the historic culture of national patriotism and comprehensively embody the spirits of national minorities, namely, supporting the army and cherishing the Party as well as Uniting for struggle. Last but not the least, it should lay emphasis on the construction of "Tourism plus" and wisdom tourism platform in order to provide tourists with a comprehensive information consultation including food, housing, transportation, traveling, purchasing and entertaining.

Train International Talents of Red Tourism. Language barrier is another important factor restricting the internationalization of red tourism in Guangxi. Therefore, under the large environment of international development of red tourism in Guangxi, it is necessary to cultivate tour guides, 
instructors and attendants who perfectly master all kinds of foreign language skills. It is especially significant to pay attention to the cultivation of talents on minority languages in ASEAN countries to be directly docked with the main source countries of ASEAN, thus facilitating to solve the language barriers occurred in the process of internationalization of red tourism in Guangxi. It is also of great importance to formulate human resource training policy of red tourism in the whole district and human resource selection plan so as to improve the relevance and effectiveness, thus constantly optimizing the human resource structure of red tourism. It is required to intensify the training on employees and leaders of relevant departments to enhance their awareness on red tourism development. At the same time, it is urgent to cultivate and introduce urgently-needed professionals and the construction of different layers of talents of red tourism. Also, it is necessary to integrate a variety of education and training resources and perfect the personnel training system. Feasible measures should be developed to fully mobilize the enthusiasm and creativity of tourism administrative departments, training institutions, universities, research institutes and so on so forth. What's more, it is vital to standardize education and training activities, pay close attention to the compilation of teaching materials, establish standardization system for vocational skills, and formulate socialized regime of Station Incumbency Certificate. It is of same importance to reinforce the construction of teaching troop, improve the quality and attainment of personnel. It is supportive to set up red tourism courses for colleges of tourism, intensify the talent pool of red tourism. Cooperation between colleges and enterprises is encouraged to carry out to build Patriotism Education Base and Red Tourism Training Base in the whole district. Lastly, it is noted to make full use of the network platform to achieve the sharing of educational resources.

Develop International Lines of Red Tourism. Guangxi and Socialist Republic of Vietnam are close neighbors connected by the same waters, which shares the border line of $637 \mathrm{~km}$. Because of a common social system, the two countries have an obvious cooperative advantage in red tourism. As one of the Internationally Cooperated Zones of Red Tourism in China, Chongzuo, Guangxi is able to develop transnational red tourism routes themed as revolutionary friendship between China and Vietnam by employing the border line. Taking red tourism routes such as "Trip followed by Ho Chi Minh", it is necessary to push forward the international development of red tourism in Guangxi. In addition, it is vital to encourage the cross-border cooperation between China and Vietnam to require both parties continue to give full play of planning and coordination of China-Vietnam Steering Committee on Cooperation so as to jointly promote the construction of "The Belt and Road" and "Two Corridors and One Ring", thus achieving the normalization of tourism cooperation. In addition, attention should be focused on enhancing the level of characteristic tourism integrating shopping, leisure, business and other functions as a whole and coordinating to develop bordering and cross-bordering red tourism products, thus forming a multi-level and diversified system for red tourism products and building a "Beibu Gulf Economic Zone: Oriented towards ASEAN" which gathers cultural experience, health preservation, business and leisure together.

\section{Conclusions}

Guangxi Province is supposed to well seize the opportunity of leaping development for its tourism. Tightly combined with the practical conditions of red tourism in Guangxi, it should profoundly dig out the connotation of red culture and improve the top-quality tourist routes of red tourism. At the same time, it is necessary to strengthen international publicity and cultivation of international talents so as to better play the political benefits, social benefits and economic benefits of red tourism, thus accelerating to realize the leaping development of red tourism in Guangxi.

\section{References}

[1] Red Tourism to Promote Students' Socialism Core Values Education-Gulin Tourism College as an Example [J]. Education Teaching Forum, 2017(6): 38-39. 
[2] Cheng Yao, Li Tianxue, The Research on the Integration of Development of Red Tourism and Cultural Industry in Guilin [J]. Journal of Guilin Normal College, 2016, 30(4): 1-4+16.

[3] Yu Yi, Meng Ting, Research on the Characteristics and C-E Translation of Publicity Materials for Red Tourism in Guilin [J]. Journal of Nanning Polytechnic, 2015, 20(1): 97-100.

[4] Zhu Zhiqiang, Lin Lan, Yang Shu, Tan Bo, The Mapping Knowledge Domainsabout Development of Domestic Red Tourism Research Bibliometric Analysis based on Cite Space [J]. Tourism Forum, 2016, 9(6): 32-39. 